\title{
ANALISIS KANDUNGAN KARBOHIDRAT TERLARUT TOTAL PLANLET BUNCIS (Phaseolus vulgaris L.) MENGGUNAKAN METODE FENOL-SULFUR SECARA IN VITRO
}

\author{
Endang Nurcahyani ${ }^{1}$, Nurul Aniqotun Mutmainah ${ }^{2}$, Salman Farisi $^{2}$, Rochmah Agustrina ${ }^{2}$ \\ ${ }^{1}$ Program Studi Biologi Terapan, Jurusan Biologi, FMIPA, Universitas Lampung \\ ${ }^{2}$ Program Studi Biologi, Jurusan Biologi, FMIPA, Universitas Lampung \\ endang.nurcahyani@fmipa.unila.ac.id
}

\begin{tabular}{|l|}
\hline Artikel Info \\
\hline Diterima \\
tanggal \\
12.12 .2018 \\
\\
Disetujui \\
publikasi \\
tanggal \\
30.04 .2019 \\
\\
Kata kunci: \\
Cekaman \\
kekeringan, In \\
vitro, \\
Phaseolus \\
vulgaris L., \\
Rhizoctonia \\
solanii \\
\hline
\end{tabular}

\begin{abstract}
ABSTRAK
Buncis merupakan salah satu jenis kacang-kacangan yang cukup populer dikalangan masyarakat karena memiliki kandungan gizi yang tinggi dan memiliki potensi nilai ekonomi-sosial yang baik serta berdaya guna untuk mempertahankan kesuburan tanah. Rhizoctonia solanii merupakan salah satu mikoriza yang dapat dimanfaatkan untuk membantu meningkatkan proses penyerapan air tanah pada saat tanaman sedang mengalami cekaman kekeringan. Penelitian ini bertujuan untuk mengetahui efek pemberian Rhizoctonia solanii pada kandungan karbohidrat planlet buncis (Phaseolus vulgaris L.) dalam kondisi cekaman kekeringan secara in vitro. Penelitian ini menggunakan Rancangan Acak Lengkap Faktorial dengan 2 faktor, yaitu inokulasi Rhizoctonia dengan 2 taraf $\left[\mathrm{V}_{0}\right.$ (tidak diinokulasi Rhizoctonia) dan $\mathrm{V}_{1}$ (diinokulasikan Rhizoctonia)] dan konsentrasi Poly Ethylene Glycol (PEG 6000) dengan 3 taraf $\left[\mathrm{P}_{0}(0 \%), \mathrm{P}_{1}\right.$ $(15 \%)$ dan $\mathrm{P}_{2}(30 \%)$ ]. Data dianalisis dengan menggunakan ANOVA dan uji lanjut dengan Beda Nyata Terkecil (BNT) pada taraf nyata $5 \%$. Masingmasing konsentrasi dilakukan 4 kali ulangan dan setiap ulangan terdiri dari 3 biji buncis dalam setiap botol kultur. Hasil penelitian menunjukkan
\end{abstract} bahwa inokulasi mikoriza Rhizoctonia solanii belum memberikan pengaruh terhadap kandungan karbohidrat terlarut total planlet buncis dalam kondisi cekaman kekeringan secara in vitro.

\begin{abstract}
Beans are one type of beans that are quite popular among the community because they have high nutritional content and have the potential for good and useful economic-social value to maintain soil fertility. Rhizoctonia solanii is one of the mycorrhizae that can be used to help improve the process of absorption of ground water when plants are experiencing drought stress. This study aims to determine the effect of Rhizoctonia solanii on the carbohydrate content of plantlets beans (Phaseolus vulgaris L.) in drought stress conditions in vitro. This study used a Factorial Completely Randomized Design with 2 factors, namely Rhizoctonia inoculation with 2 levels [VO (not Rhizoctonia inoculated) and VI (Rhizoctonia inoculated)] and Poly Ethylene Glycol (PEG 6000) concentration with 3 levels [P0 (0\%), P1 (15\%) and P2 (30\%)]. Data were analyzed using ANOVA and continued with Least Significant Difference (LSD) at the 5\% significance level. Each concentration is done four replications and each replication consisted of three beans in each culture bottle. The results showed that the inoculation of mycorrhizal Rhizoctonia solanii not give effect to the total carbohydrate content of chickpeas plantlets in drought stress conditions in vitro.
\end{abstract}

doi: http://dx.doi.org/10.23960/aec.v4.i1.2019.p73-80

Anal.Environ.Chem.Anal.Environ.Chem 


\section{PENDAHULUAN}

Buncis merupakan salah satu jenis kacang-kacangan yang cukup populer dikalangan masyarakat karena memiliki kandungan gizi yang tinggi dan potensi nilai ekonomi-sosial yang cukup baik serta berdaya guna untuk mempertahankan kesuburan tanah (Gardner, 1991). Menurut Amin (2014) buncis berkhasiat mencegah dan mengobati Diabetes mellitus. Berdasarkan data dari Badan Pusat Statistik Republik Indonesi (BPS RI, 2011), buncis masuk ke dalam kategori 15 sayuran yang banyak dikonsumsi oleh masyarakat Indonesia.

Berdasarkan kondisi tersebut, petani di Indonesia terus berupaya untuk meningkatkan hasil panen buncis, namun ada kalanya hasil panen para petani tidak maksimal, penyebabnya antara lain musim yang tidak menentu seperti musim kemarau yang berkepanjangan (Gunawan \& Azhari, 2010), yang menyebabkan tanah kering dan tanaman mengalami cekaman kekeringan. Cekaman kekeringan pada tanaman adalah kondisi saat tanaman kekurangan suplai air dari lingkungan tempat tumbuhnya. Kekurangan kandungan air pada tanaman akan mempengaruhi proses pembelahan dan pembesaran sel, juga dapat menyebabkan penurunan kandungan klorofil dalam kloroplas (Sartika et al., 2008).

Faktor lain yang menyebabkan rendahnya produktivitas buncis ialah sistem pengairan pada lahan-lahan pertanian yang masih sangat rendah. Petani sayuran dataran tinggi masih memanfaatkan curah hujan sebagai satu-satunya sumber pengairan, sehingga pada musim kemarau mereka harus menanam komoditas yang toleran terhadap kekeringan seperti jagung putih, tembakau, tanaman menahun yang diperkirakan dapat dipanen pada pertengahan musim kemarau seperti teh atau kopi (Norman \& Hooker, 2017).

Salah satu upaya dalam mengatasi masalah rendahnya produktivitas buncis adalah dengan memanfaatkan mikroorganisme seperti mikoriza. Tanaman bersimbiosis dengan mikoriza pada bagian akar tanaman dalam proses penyerapan unsur hara. Mikoriza dialam berperan dalam memperbaiki ketersediaan hara dan meningkatkan pertumbuhan tanaman serta mempertahankan keanekaragaman tumbuhan. Mikoriza juga dapat meningkatkan kemampuan tanaman dalam menghindari kekeringan dengan jalan meningkatkan penyerapan air melalui sistem simbiosis antara akar dan mikoriza. Hifa mikoriza membantu menyerap air dari poripori tanah saat akar sudah kesulitan dalam menyerap air. Simbiosis ini menjadikan tanaman tumbuh dengan baik pada kondisi kekeringan (Rita \& Djajadi., 2009). Rhizoctonia solanii merupakan salah satu mikoriza yang dapat dimanfaatkan untuk membantu meningkatkan proses penyerapan air tanah pada saat tanaman sedang mengalami cekaman kekeringan (Anjum et al., 2011). 
Pengujian respon buncis terhadap kekeringan dapat dilakukan dengan cara simulasi kondisi kekeringan menggunakan Poly Ethylen Glycol(PEG). Penggunaan PEG menyebabkan penurunan potensial air secara homogen sehingga dapat digunakan untuk meniru besarnya potensial air tanah. PEG memiliki kelebihan yaitu tidak dapat diserap tanaman karena PEG bersifat polar, sehingga mampu mengikat air dan menyebabkan potensial air menurun, meskipun ketersedian air tetap ada tetapi tanaman tidak mampu memperoleh air. Besarnya potensial air tergantung pada konsentrasi PEG (Michel \& Kaufman, 1973).

Karbohidrat merupakan suatu golongan senyawa yang terdiri dari atau dapat dihidrolisis menjadi polisakarida aldehid dan keton. Karbohidrat dalam tanaman berupa amilum atau pati. Amilum adalah homopolimer (suatu polimer yang terbentuk oleh hanya satu macam unit monomerik) dari glukosa yang digabung oleh mata rantai yang sama dengan maltosa. Macam amilum utama adalah amilosa dan amilopektin (bila dilarutkan dengan iodin memberikan warna merah ungu), sedangkan amilosa memberikan warna biru (Fressenden, 1997).

Proses fotosintesis akan menghasilkan karbohidrat, terutama glukosa, diantara berbagai karbohidrat yang penting dapat dibentuk oleh tumbuhan dari glukosa adalah selulosa, sukrosa dan pati atau amilum. Amilum didalam tumbuhan banyak tersimpan dalam akar, umbi atau biji-bijian, butir-butir amilum itu sebenarnya semula terdapat di dalam kloroplas daun sebagai hasil fotosintesis. Pada kebanyakan tumbuhan dikotil juga monokotil, pati mulai terkumpul pada daun segera setelah terjadi proses fotosintesis yang berjalan cepat, sehingga pada tanaman dikotil mempunyai daun pati sedangkan tanaman monokotil mempunyai daun gula (Loveless, 1994).

Pembentukan pati terjadi melaui suatu proses yang melibatkan sumbangan berulang unit glukosa dari gula nukleotida serupa dengan UDPG yang disebut adenosin difosfoglukosa, ADPG. Pembentukan ADPG berlangsung dengan menggunakan ATP dan glukosa-1-fosfat di kloroplas dan plastid (Dwijosepoetro, 1994; Lakitan, 2000; Salisbury \& Ross,1992). Molekul amilosa yang sedang tumbuh dengan unit glukosa yang mempunyai gugus reaksi C-4 pada ujungnya, bergabung dengan C-1 glukosa yang ditambahkan dari ADPG. Pati sintetase, yang mengkatalisis reaksi tersebut diaktifkan oleh $\mathrm{K}+$. Cabang pada amilopektin antara C-6 pada rantai utama dan C-1 pada rantai cabang dibentuk oleh berbagai isoenzim dari beberapa enzim yang secara ringkas disebut enzim percabangan atau enzim Q. Tingkat cahaya yang tinggi dan siang hari yang panjang, menguntungkan fotosintesis dan translokasi karbohidrat, sehingga menyebabkan penimbunan satu atau lebih butir pati di kloroplas dan penyimpanan pati di 
amiloplas. Pembentukan pati di kloroplas diuntungkan oleh cahaya terang, sebab enzim yang membentuk ADPG secara alosetrik diaktifkan oleh 3-PGA dan dihambat secara alosetrik Pi (Preiss). Kandungan 3-PGA agak meningkat saat terang sewaktu penambahan $\mathrm{CO}_{2}$ terjadi, tetapi kandungan Pi agak menurun karena ditambah ADP untuk membentuk ATP selama fosforilasi fotosintesis (Salisbury \& Ross, 1992).

Penggunaan teknik in vitro atau kultur jaringan dalam mempelajari cekaman kekeringan memberikan keuntungan yaitu dapat membuat medium tanam steril dari mikroorganisme yang merugikan, dapat digunakan untuk melakukan simulasi cekaman kekeringan dengan menggunakan Poly Ethylene Glycol (PEG), dan menghasilkan bahan tanam unggul secara massal dan cepat (Putri, 2015). Pada tanaman yang mengalami cekaman kekeringan, tanaman berasosiasi dengan mikoriza arbuskular untuk membantu meningkatkan usur hara dan air dari dalam tanah melalui hifa yang terikat pada jaringan akar dan batang. Tanaman yang diinokulasi mikoriza telah banyak digunakan dalam peningkatan kualitas tanaman. Peningkatan kualitas pemuliaan tanaman yang diinokulasi mikoriza telah banyak dilaporkan di berbagai tanaman (Nurcahyani et al., 2017).

Sejauh ini belum ada penelitian yang menggunakan mikoriza Rhizoctonia solanii pada planlet buncis dalam kondisi cekaman kekeringan secara in vitro, oleh karena itu peneitian ini menarik untuk dilakukan.

\section{METODE}

\section{Alat dan Bahan}

Alat- alat yang digunakan dalam penelitian ini adalah alumunium foil, Autoclave, Laminar Air Flow Cabinet (LAF) ESCO, pinset, scalpel, mata pisau scalpel, kertas filter, Erlenmeyer berukuran $50 \mathrm{ml}$, cawan petri berdiameter $10 \mathrm{~cm}$, corong, botol kultur berukuran $250 \mathrm{ml}$, gelas ukur bervolume $100 \mathrm{ml}$ dan $500 \mathrm{ml}$, kertas label, mikroskop, mikropipet, pipet tip, spektrofotometri (Shimudzu UV 800), tabung reaksi, rak tabung reaksi, timbangan analitik Ohaus, tisu, waterbatt, dan kamera nikon coolpix.

Bahan yang digunakan adalah eksplan berupa biji Phaseolus vulgaris L. steril dalam botol kultur, isolat jamur Rhizoctonia solanii yang diperoleh dari Temanggung, jawa Tengah, Poly Ethylene Glycol (PEG) 6000, alkohol 70 \%, akuades, sukrosa, Plant Preservative Mixture (PPM), Kalium Hidroksida $(\mathrm{KOH})$, Asam Chlorida $(\mathrm{HCl})$, serta bahan kimia medium Murashige \& Skoog (MS) padat. 


\section{Prosedur}

Pembuatan medium tanam MS sebanyak 1 liter adalah dengan cara menimbang medium dasar Murashige dan Skoog use ready. Untuk pembuatan medium 1 liter dibutuhkan MS use ready sebanyak 4,43 gram,yang dilarutkan dengan sukrosa $30 \mathrm{~g} / \mathrm{l}$, dan akuades sebanyak 1 liter dalam beaker glass. Larutan tersebut kemudian dipindahkan ke dalam wadah yang lebih besar kemudian ditambahkan agar-agar sebanyak $7 \mathrm{~g} / \mathrm{l}$, dan sukrosa $30 \mathrm{~g} / \mathrm{l}$. Sterilisasi medium menggunakan autoklaf dengan tekanan 17,5 psi, $121{ }^{\circ} \mathrm{C}$ selama 15 menit. Medium Murashige \& Skoog (MS) padat selanjutnya ditambah Poly Ethylene Glycol (PEG) 6000 dengan konsentrasi $0 \%$ (kontrol), $15 \%$, dan $30 \%$. Sebelum digunakan, PEG 6000 dilarutkan dengan akuades pada konsentrasi tertentu disaring menggunakan syringe filter yang mempunyai diameter $0,45 \mu \mathrm{m}$ sebanyak 2 kali, dilanjutkan filter berdiameter $0,22 \mu \mathrm{m}$ satu kali. Penyaringan dilakukan dalam ruang steril didalam LAF Cabinet, selanjutnya PEG 6000 ditambahkan ke dalam medium MS. Sebelum digunakan, medium diinkubasikan selama 7 hari pada suhu kamar $\left(25^{\circ} \mathrm{C}\right)$ untuk memastikan bahwa PEG 6000 telah tersaring dengan baik. Apabila dalam waktu 7 hari tidak terjadi kontaminasi pada medium, maka medium dapat digunakan.

Inokulasi Rhizoctonia solanii dilakukan secara langsung pada medium tanam buncis secara in vitro dengan menambah larutan isolat $R$. solanii yang dimasukkan pada medium Murashige \& Skoog (MS) sebanyak 0,1 ml dan diinkubasikan pada suhu kamar selama 72 jam.

Sterilisasi biji dilakukan dengan cara merendam biji dengan aquades steril selama 15 menit lalu dilanjutkan dengan merendam biji pada larutan bayclean $10 \%$ selama 5 menit, lalu dibilas dengan aquades steril selama 5 menit dan dilakukan senyak 3 kali pengulangan. Semua kegiatan ini dilakukan dalam ruang steril di dalam LAFC. Penanaman biji buncis dilakukan di dalam LAFC. Setiap botol kultur ditanami 3 biji, sehingga total biji yang ditanam sebanyak 72 biji dalam 24 botol kultur. Biji buncis tersebut ditumbuhkan hingga menjadi planlet. Inkubasi kultur dilakukan pada ruangan.

Analisis kandungan karbohidrat terlarut total dilakukan dengan metode fenol-sulfur (Dubois et al., 1956). Planlet buncis diambil dan ditimbang sebanyak 0,1 gram, kemudian ditumbuk dengan mortar lalu diberi $10 \mathrm{ml}$ akuades, disaring dengan kertas saring Whatman no. 1 lalu dimasukkan kedalam tabung reaksi. Filtrat diambil sebanyak $1 \mathrm{ml}$ dan ditambahkan $1 \mathrm{ml}$ $\mathrm{H}_{2} \mathrm{SO}_{4}$, selanjutnya ditambahkan fenol sebanyak $2 \mathrm{ml}$. Berikutnya filtrat dimasukkan kedalam kuvet dan dibaca pada panjang gelombang $490 \mathrm{~nm}$. 


\section{HASIL DAN PEMBAHASAN}

Kebutuhan air pada setiap tanaman berbeda tergantung jenis tanaman dan fase pertumbuhannya. Air sangat penting dalam proses metabolisme tanaman, semakin minimnya air akan mengakibatkan proses metabolisme terganggu. Kekurangan air pada tanaman mengakibatkan dehidrasi tanaman dan menurunkan tekanan turgor sel. Hal tersebut dapat merangsang penutupan stomata sehingga difusi $\mathrm{CO}_{2}$ dan aktivitas fotosintesisi terhambat (Levit, 1980).

Karbohidrat terlarut total digunakan sebagai salah satu parameter untuk mengetahui ketahanan planlet buncis terhadap kondisi cekaman kekeringan. Peningkatan kandungan karbohidrat terlarut ini terjadi pada tanaman dalam upaya mempertahankan dari kondisi cekaman kekeringan. Menurut Masuko et al. (2005) kandungan karbohidrat pada batang tanaman merupakan parameter yang digunakan dalam analisis dasar biosains. Kandungan karbohidrat terlarut total merupakan parameter yang tepat untuk mengkaji akibat dari cekaman kekeringan. Karbohidrat berperan dalam mengatur tekanan osmotik pada saat tanaman mengalami cekaman kekeringan dan dapat diamati pada batang karena batang adalah bagian tumbuhan yang banyak mengandung gula (Kerepesi \& Galiba, 2000). Rata-rata kandungan karbohidrat terlarut total batang planlet buncis yang diberi berbagai konsentrasi PEG 6000 serta diinokulasi maupun tidak diinokulasi mikoriza pada medium MS disajikan pada Tabel 1.

Tabel 1. Rata-rata kandungan karbohidrat terlarut total planlet buncis pada pengamatan minggu ke-2

\begin{tabular}{ccccc}
\hline \multirow{2}{*}{$\begin{array}{c}\text { Inokulasi } \\
\text { Rhizoctonia }\end{array}$} & \multicolumn{3}{c}{ Konsentrasi PEG 6000 (\%) } & \multirow{2}{*}{ Nilai tengah } \\
\cline { 2 - 4 } & $\mathbf{0}$ & $\mathbf{1 5}$ & $\mathbf{3 0}$ & \\
\hline Tanpa Inokulasi & $1,339 \pm 0,050$ & $1,329 \pm 0,141$ & $1,334 \pm 0,029$ & 1,407 \\
\hline Inokulasi & $1,319 \pm 0,032$ & $1,322 \pm 0,028$ & $1,422 \pm 0,097$ & 1,406 \\
\hline Nilai tengah & 1,329 & 1,325 & 1,388 & \\
\hline
\end{tabular}

Ketererangan :

Tinggi total $=\tilde{\mathbf{Y}} \pm \mathrm{SE}$

$\tilde{\mathbf{Y}}=$ Rata-rata kandungan karbohidrat total

$\mathrm{SE}=$ Standart error

Analisis ragam menunjukkan bahwa pemberian inokulasi $R$. solanii dan PEG 6000 tidak memberikan pengaruh nyata terhadap kandungan karbohidrat terlarut total planlet buncis. Interaksi yang terjadi antara inokulasi $R$. solanii dan PEG 6000 terhadap kandungan karbohidrat total adalah tidak nyata. Hal ini menunjukkan bahwa pemberian inokulasi $R$. 
solanii tidak memberikan pengaruh dalam meningkatkan kandungan karbohidrat total planlet buncis pada kondisi cekaman kekeringan. Hal ini terjadi karena kemungkinan planlet buncis belum dapat memproduksi karbohidrat dengan baik, terbukti dengan masih adanya kotiledon yang menempel pada planlet, ini menunjukkan bahwa planlet belum maksimal dalam melakukan fotosintesis dan masih menggunakan cadangan makanan pada kotiledon dalam pertumbuhannya.

Kandungan karbohidrat dipengaruhi oleh beberapa faktor luar. Faktor-faktor yang berpengaruh terhadap penyusunan amilum menurut Purwanto \& Agustono (2010) diantaranya pengaruh air. Daun yang layu di dalamnya banyak terdapat amilum terubah menjadi gula sukrosa dan beberapa monosakarida. Persediaan air yang agak berlebihan menambah kegiatan penyusunan amilum; Konsentrasi ion-ion $\mathrm{H}+$, perubahan $\mathrm{pH}$ membawa perubahan kegiatan enzim. Enzim akan bekerja berlawanan jika lingkungannya mengalami perubahan $\mathrm{pH}$. Pada $\mathrm{pH}$ di atas 7 banyak terbentuk gula sedang gula akan terbentuk menjadi amilum lagi jika $\mathrm{pH}$ turun sampai di bawah 7 .

\section{KESIMPULAN}

Berdasarkan penelitian yang telah dilakukan dapat disimpulkan bahwa inokulasi Rhizoctonia solanii tidak memberikan pengaruh nyata terhadap peningkatan kandungan karbohidrat terlarut total pada kondisi cekaman kekeringan secara in vitro pada planlet buncis.

\section{DAFTAR PUSTAKA}

Amin, MN. 2014. Sukses Bertani Buncis: Sayuran Obat Kaya Manfaat. Garudhawacana.

Anjum, S.A., X.Y. Xie., L.C.Wang., M.F. Salem., C. Man., \& W. Lei. 2011. Morphological, Physiological, and Biochemical Responses of Plants to Drought Stress. African J. of Agric. Res. 6(9): 2026 - 2032.

BPS Republik Indonesia. 2011. Statistik Tanaman Sayuran dan Buahan Semusim Indonesia 2010. Badan Pusat Statistik. Jakarta.

Dubois, M., K.A. Gille, J.K. Hamilton, P.A. Rebers, dan Smith, F. 1956. Colometri method for Determination of Sugars and Related Subtance. Anal. Biochem 28(1956): 143-145.

Dwidjoseputro, D., 1994, Pengantar Fisiologi Tumbuhan, PT Gramedia, Jakarta.

Fressenden R. J., 1997, Plant and Introduction to Modern Botany, Macmillan Publishing Co., Inc, New York.

Gardner, F.P., R.B. Pearce dan R. L. Mitchell. 1991. Fisiologi Tanaman Budidaya. Penerjemah : H. Susilo. Universitas Indonesia Press. Jakarta. Hal. 112-113.

doi: http://dx.doi.org/10.23960/aec.v4.i1.2019.p73-80

Anal.Environ.Chem.Anal.Environ.Chem 
Gunawan, B. dan C. D. Azhari.2010. Karakterisasi Spektofotometri dan Scaning

Electron Microcopy (SEM) Sensor Gas dari Bahan Polimer Poly-Etilene Glycol (PEG). Jurnal ISSN :1979-6870

Kerepesi, I., \& Galiba. 2000. Osmotic and Salt Stress-Induced Alteration in Soluble Carbohydrate Content in Wheat Seedlings. Crop Science 40(2000): 482-487.

Lakitan, 2000, Fisiologi Tanaman, PT Bina Aksara, Jakarta.

Loveless, 1994, Study Guide to Accompany Botany, Chesther Bistane Toronto, Singapore

Levitt, J. 1980. Responses of plants to environmental stresses: Water, radiation, salt, and other stresses. Vol. II. Academic Press. New York.

Masuko, T., M, Akio, I. Norimasa, T. Majima, N. Shin-Ichiro, dan Y.C. Lee. 2005. Carbohydrate Analysis by A Phenol-sulfuric Acid Method In Microplate Format.Analytical Biochemistry Vol 339.

Michele, R. E dan M. R. Kaufman. 1973. Osmotic potential of polyethylene glikol 6000. Plant Physiology. Vol 5 : 914-916.

Norman, J. R and J.E Hooker. 2017. Sporulatoin of Phytophthora fragaria show grater stimulation axudates of non-mycorrhizal than by mycorrhizal strawberry roots. Mycol. Vol 104: 1069-1073

Nurcahyani, E., I. Sumardi, B. Hadisutrisno, dan E. Suharyanto. 2017. DNA Pattern Analysis of Vanilla planifolia Andrews Plantae Which Resistant to Fusarium oxysporum f.sp vanillae. World Journal of Pharmaceutical and Life Sciences.3(4). ISSN 2454-2229.

Purwanto, dan Agustono T. 2010. Kajian Fisiologi Tanaman Kedelai pada Cekaman Kekeringan dan Berbagai Kepadatan Gulma Teki. Agrobisnis : Vol 12 (1). 24-28.

Putri, Y. S. 2015. Pertumbuhan Kalus Stevia Rebaudiana Bertoni Dari Eksplan Daun dan Ruas Batang Dengan Periode Subkultur Berbeda. Skripsi. Departemen Biologi MIPA. IPB. Bogor.

Rita, H. dan Djajadi. 2009. Sifat-sifat tanah yang memengaruhi perkembangan patogen tular tanah pada tanaman tembakau. J. Perspektif 8(2): 74-83.

Sartika, Y., Nurbaity, A., Sofyan, E. 2008. Efek Sterilisasi dan Komposisi Media Inokulan Konsorsium Mikoriza Arbuskular dan Mycrrhizal helper bacteria Terhadap Jumlah Spora MA, Populasi MHB, dan Nisbah Pupus Akar Sorgum. Agric Sci Jurnal. Vol 1(4): $262-268$

Salisburry, F. B. dan Ross W. C., 1992, Fisiologi Tumbuhan Jilid 2, ITB Press, Bandung. 